\title{
Estructura porosa y proceso de carbonatación en pastas mixtas de cal con diferente porcentaje de cemento
}

\section{Pore structure and carbonation in blended lime-cement pastes}

\author{
M. Arandigoyen y J. I. Álvarez ${ }^{(*)}$
}

Recepción/Received: 4-X-05

Aceptación/Accepted: 21-XII-05

\section{RESUMEN}

En este trabajo se estudia el proceso de carbonatación en pastas mixtas de cal y cemento $(100,90,80,70,60$, 50 y $40 \%$ de cal) con el objeto de obtener un mejor conocimiento del proceso de curado en estos materiales. Para ello se ha empleado una cal aérea hidratada en polvo y un cemento Portland del tipo CEM II A/L 32,5. En particular, este estudio investiga estos materiales ya que pueden ser utilizados en la restauración del Patrimonio Cultural. Se ha utilizado la variación de peso como indicador del proceso de carbonatación. Se ha establecido un nuevo parámetro, $A$, que varía inversamente con el porcentaje de cemento en la pasta, debido al predominio de la difusión de Knudsen como consecuencia de la estructura porosa, que ha sido estudiada por medio de porosimetría de intrusión de mercurio (PIM). El estudio higroscópico realizado sobre las diversas pastas permite conocer el contenido en agua a una determinada humedad y si ésta se adsorbe sobre la superficie de los poros o condensa en ellos bloqueando la difusión del $\mathrm{CO}_{2}$. Del estudio del proceso de curado, se puede concluir que ni el proceso de secado ni la hidratación de $\mathrm{C}_{3} \mathrm{~S}$ retrasan el proceso de carbonatación de la cal de la mezcla.

Palabras clave: cinética, microestructura, carbonatación, pasta de cemento, cal.

\section{SUMMARY}

The present study aims to gain a fuller understanding of the curing process in lime pastes (100, 90, 80, 70, 60,50 and $40 \%$ lime) blended with cement by analyzing carbonation in these materials. A hydrated, air slaked lime powder and CEM II A/L 32.5 Portland cement were used for the blends. These materials were singled out for research primarily because they may be used in the restoration of heritage monuments. Variation in weight was used as an indicator for carbonation. A new parameter, $A$, was found to vary inversely with the percentage of the cement because of the prevalence of Knudsen diffusion in the paste, in turn due to the characteristics of the pore structure, which was studied by mercury intrusion porosimetry (MIP). The hygroscopic study conducted on the different pastes provided information on water content at a given humidity and its location, i.e., adsorbed on the surface of the pores or condensed inside them, obstructing the diffusion of $\mathrm{CO}_{2}$. The conclusion drawn from this study of the curing process was that neither drying nor $C_{3} S$ hydration retarded lime carbonation.

Keywords: kinetics, microstructure, carbonation, cement paste, lime.

(*) Departamento de Química. Universidad de Navarra, Navarra (España).

Persona de contacto/Corresponding author: jalvarez@unav.es (J. I. Álvarez). 


\section{INTRODUCCIÓN}

Actualmente se desarrolla una importante búsqueda de materiales conglomerantes nuevos y modificados para su empleo en trabajos de restauración del Patrimonio Cultural $(1,2)$. El propósito de estos materiales es buscar un sustituto adecuado a los morteros de cal que compensen su lento fraguado y su baja resistencia mecánica, aunque tampoco se trata de incorporar un mortero puro de cemento, debido a su ya comprobada mala compatibilidad con los materiales antiguos (mortero y piedra), originando, por ejemplo, alteraciones debidas a su elevado contenido en sales solubles (3).

El uso de morteros mixtos, basados en mezclas de cal y cemento, puede disminuir las desventajas de cada tipo de mortero, manteniendo los aspectos favorables de cada uno de ellos (los morteros de cal presentan alta compatibilidad con los materiales antiguos, y tienen bajas cantidades de sales solubles, mientras que los morteros de cemento ofrecen altas resistencias mecánicas y cortos tiempos de fraguado) $(1,2)$.

Un aspecto importante en estos conglomerantes mixtos es conocer el desarrollo de las resistencias mecánicas, tarea que precisará un futuro trabajo. Específicamente, y como se ha comprobado en las distintas referencias (1, 2), la carbonatación del hidróxido de calcio es un proceso destacado en el desarrollo de estas resistencias, y su estudio es el que fundamenta el presente trabajo. En una pasta de cal pura el proceso de la carbonatación puede evaluarse siguiendo la variación del peso como consecuencia de la absorción del $\mathrm{CO}_{2}$ y la desorción de agua [1]:

\section{INTRODUCTION}

An intensive search is presently underway for new and modified binders for use in cultural heritage restoration projects $(1,2)$. The ultimate aim is to find a suitable replacement for slow setting, low strength lime mortars. Pure cement mortars have likewise been ruled out for this use, in light of their poor compatibility with historic materials (mortar and stone), which are altered by the high soluble salt content in cement (3).

Blended mortars based on lime and cement mixes may reduce the drawbacks while maintaining the strong points of each type of pure mortar (lime mortars are highly compatible with historic materials and have a low soluble salt content, whereas cement mortars feature high mechanical strength and short setting times) $(1,2)$.

One important issue not addressed here, the development of mechanical strength in these binders, will be the object of further research. Specifically, the literature shows $(1,2)$ that calcium hydroxide carbonation, the core subject of the present study, is a prominent process in such development. In a pure lime paste, carbonation may be assessed in terms of the variation of weight resulting from the absorption of $\mathrm{CO}_{2}$ and water desorption [1]:

$$
\mathrm{Ca}(\mathrm{OH})_{2}+\mathrm{CO}_{2} \rightarrow \mathrm{CaCO}_{3}+\mathrm{H}_{2} \mathrm{O}
$$

A pesar de que la mayoría de los autores estudian el proceso de la carbonatación evaluando el avance del frente de carbonatación (4-6), son innegables los dos problemas asociados a este procedimiento de estudio: i) irregularidad del frente de carbonatación, ii) amplitud de la interfase (5-7). Por lo tanto, podría resultar interesante disponer de otro parámetro de evaluación más concreto y objetivable. En este trabajo se postula analizar la carbonatación teniendo en cuenta la variación de peso. De esta forma, se evitan los problemas antes mencionados correspondientes a la evaluación del frente de carbonatación.

Durante el curado de las pastas preparadas con conglomerantes mixtos tienen lugar tres procesos principalmente: i) secado del agua de amasado; ii) carbonatación del hidróxido de calcio; iii) hidratación de los silicatos cálcicos del cemento. Por varias razones, la carbonatación está influenciada fuertemente por la microestructura de
Although most authors study carbonation in terms of the progression of the carbonation front (4-6), two problems are indisputably associated with this approach: i) irregularity of the carbonation front, ii) breadth of the interface (5-7). Another more specific and objective parameter may, therefore, prove to be very useful. The present paper propounds analyzing carbonation on the grounds of variations in weight. This obviates the problems discussed above in connection with carbonation front-based assessment.

Three main processes take place during blended binder curing: i) mixing water drying; ii) calcium hydroxide carbonation; iii) calcium silicate hydration. Carbonation is acutely affected by the microstructure of the material for a number of reasons: i) $\mathrm{CO}_{2}$ diffusion depends on pore size and the intricacy of the system $(4,8,9)$; ii) $\mathrm{Ca}(\mathrm{OH})_{2}$ 
los materiales, dado que: i) la difusión del $\mathrm{CO}_{2}$ es función del tamaño de poro y de la tortuosidad del sistema $(4,8$, $9) ;$ ii) la disolución del $\mathrm{Ca}(\mathrm{OH})_{2}$ depende del área de contacto entre los cristales de $\mathrm{Ca}(\mathrm{OH})_{2}$ y el contenido en agua, cuya cantidad también depende de la estructura interna de la pasta $(5,10,11)$.

El propósito de esta investigación es el estudio del proceso de carbonatación por registro de la variación del peso, de forma análoga al estudio ya realizado en pastas de cal (12), teniendo en cuenta la modificación de la estructura porosa como consecuencia de los cambios de composición de las pastas. Mientras las pastas de cal tienen un tamaño de poro determinado (13), en las pastas de cemento y en las mixtas con un alto contenido en cemento predomina la estructura de gel $(14,15)$.

Es conocido que la velocidad de secado disminuye cuando el tamaño de poro del material decrece y cuando la tortuosidad se incrementa (16), por eso este artículo también evalúa la influencia del proceso de secado sobre la carbonatación de las pastas mixtas.

Este estudio podría ser aplicado a futuras investigaciones sobre la evolución de la resistencia de morteros mixtos con un mejor conocimiento del proceso de fraguado, porque hay un escaso número de trabajos de investigación que versen sobre este asunto.

\section{EXPERIMENTAL}

\subsection{Preparación de las pastas}

42 probetas prismáticas de $40 \times 40 \times 160 \mathrm{~mm}$ fueron elaboradas con una combinación de una cal comercial en polvo hidratada (Ecobat ${ }^{\circledR}$ ) y un cemento Portland (CEM II-A/L 32,5) mezclado con diferentes cantidades de agua de amasado para obtener seis pastas mixtas diferentes $(90,80,70,60,50$ y $40 \%$ de peso en cal) con una consistencia y trabajabilidad similar.

Como grupo control se incluyen a veces también los resultados de las pastas puras (100\%) de cal. Se ha descartado el estudio de pastas con un menor porcentaje de cal por dos razones: i) debido al error asociado en la adquisición de los datos como consecuencia de las pequeñas variaciones de peso, y ii) pastas con altos porcentajes de cemento no ofrecen interés como posibles materiales de reparación de obras del Patrimonio Histórico edificado, a la vista de los problemas asociados al cemento ya antes citados.

La Tabla 1 presenta la caracterización química (de acuerdo a los estándares europeos) de la cal y el cemento, y la Tabla 2 las cantidades de material mezclado. dissolution is dependent upon the contact area between the $\mathrm{Ca}(\mathrm{OH})_{2}$ crystals and the water, the amount of which likewise depends on the internal structure of the paste $(5,10,11)$.

The purpose of the present research project was to study carbonation by recording variations in weight, as in a previous study on lime pastes (12), bearing in mind the modifications in pore structure as a result of the changes in paste composition. Whereas lime pastes have a given pore size (13), gel structures predominate both in cement pastes and blends with a high cement content $(14,15)$.

The drying rate is known to decline with pore size and intensifying intricacy (16), for this reason, the present article also evaluates the effect of drying on blended paste carbonation.

This survey may make it possible to broach future research on strength development in mixed mortars with a fuller knowledge of the setting process, an issue that has received little attention in the literature to date.

\section{EXPERIMENTAL}

\subsection{Paste preparation}

Forty two $40 \times 40 \times 160 \mathrm{~mm}$ specimens were made with a combination of a commercial hydrated lime powder (Ecobat ${ }^{\circledR}$ ) and (CEM II-A/L 32.5) Portland cement mixed with varying amounts of water to obtain six different blends (90, 80, 70, 60, 50 and 40\% of lime by weight) with similar consistency and workability.

Pure (100\%) lime pastes were also included in some of the trials as a control. Studying pastes with lower lime contents was ruled out for two reasons: i) the errors associated with data readings due to the very small variations in weight, and ii) the scant applicability of pastes with high percentages of cement as possible repair materials in historic heritage buildings, due to the problems relating to the use of cement discussed above.

Table 1 gives the chemical characterization for the lime and the cement (found as specified in European Standards), and Table 2 the amounts of material used in the mixes. 
Tabla 1 / Table 1

Análisis químico de los principales componentes de la cal comercial en polvo hidratada (Ecobat $\circledast)^{a}, \mathrm{~b}$ y del cemento Portland CEM II-A/L 32,5 (\% peso)

Chemical analysis of the hydrated commercial lime powder (Ecobat $\AA$ ) $)^{a, b}$ and the Portland cement CEM II-A/L 32.5 (\% wt)

\begin{tabular}{|lcccccccc|}
\hline & P.C.c & $\mathbf{S i O}_{\mathbf{2}}$ & $\mathbf{C a O}$ & $\mathbf{M g O}$ & $\mathbf{R}_{\mathbf{2}} \mathbf{O}_{\mathbf{3}} \mathbf{d}$ & $\mathbf{S O}_{\mathbf{3}}$ & $\mathbf{N a}_{\mathbf{2}} \mathbf{O}$ \\
\hline Cal/Lime & 25.25 & 1.03 & 68.53 & 3.29 & 0.89 & 1.37 & 0.09 \\
\hline $\begin{array}{l}\text { Cemento } \\
\text { Cement }\end{array}$ & 6.94 & 16.23 & 58.28 & 4.65 & 9.99 & 2.35 & 0.05 \\
\hline
\end{tabular}

a Porcentaje referido a la cal seca original.

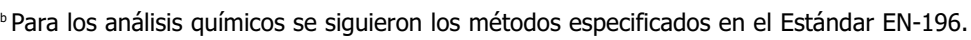

'Pérdida por calcinación, indica el peso perdido a la calcinación a 975-1.000 C.

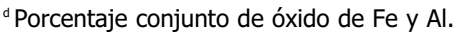

a Percentages related to original dry lime.

${ }^{b}$ The methods specified by the European Stardard EN-196 were followed for the cheminal analyses.

${ }^{c}$ Ignition loss, indicates the weight loss due to calcinations at $975-1,000{ }^{\circ} \mathrm{C}$.

${ }^{d}$ Percentage of $\mathrm{Fe}$ and $\mathrm{Al}$ oxides together.

Tabla 2 / Table 2

Cantidades de material mezcladas para elaborar las pastas Amount of material blended to elaborate the pastes

\begin{tabular}{|lcccccc|}
\hline & $\mathbf{9 0 \%}$ & $\mathbf{8 0 \%}$ & $\mathbf{7 0 \%}$ & $\mathbf{6 0 \%}$ & $\mathbf{5 0 \%}$ & $\mathbf{4 0 \%}$ \\
\hline $\begin{array}{l}\text { Cemento }(g) \\
\text { Cement }(g)\end{array}$ & 130 & 280 & 450 & 640 & 900 & 1200 \\
\hline $\begin{array}{l}\text { Cal }(\mathrm{g}) \\
\text { Lime }(g)\end{array}$ & 1170 & 1120 & 1050 & 960 & 900 & 800 \\
\hline $\begin{array}{l}\text { Agua } \\
\text { Water }(g)\end{array}$ & 1087 & 1002 & 984 & 944 & 972 & 973 \\
\hline $\begin{array}{l}\text { A/C* } \\
\text { W/B* }\end{array}$ & 0.84 & 0.72 & 0.66 & 0.59 & 0.54 & 0.49 \\
\hline
\end{tabular}

* Relación agua/conglomerante. / Water/binder ratio.

Las pastas se mezclaron durante 5 minutos en una mezcladora Proeti ETI 26.0072, incluidas en moldes prismáticos y desmoldadas trascurridos 3 días. Las probetas se curaron en una posición vertical en condiciones ambientales de laboratorio (HR $60 \pm 10 \%$ y $20 \pm 5^{\circ} \mathrm{C}$ ). El $\mathrm{CO}_{2}$ contenido en la habitación se estimó aproximadamente igual a la concentración atmosférica estándar $(0,033 \pm$ $0,001 \%$ en volumen). Tres días después, las caras de 40 x $40 \mathrm{~mm}$ fueron cubiertas con cera para que la carbonatación tuviera lugar únicamente por las caras más largas. Las muestras fueron guardadas en estas condiciones durante la evaluación de los cambios de peso. Después de la carbonatación casi completa de las pastas, establecida cuando el peso se mantiene constante, ya que siempre quedará una mínima cantidad de portlandita (17), se llevaron a cabo los análisis siguiendo la metodología descrita a continuación.
After mixing for 5 minutes in a Proeti ETI 260072 mixer, the pastes were poured into prismatic moulds from which they were removed 3 days later. The specimens were cured in a vertical position under laboratory conditions ( $\mathrm{RH} 60 \pm 10 \%$ and $\mathrm{T} 20 \pm 5^{\circ} \mathrm{C}$ ). The indoor $\mathrm{CO}_{2}$ content was estimated to be approximately equal to standard atmospheric concentration $(0.033 \pm 0.001 \%$ by volume). Three days later, the $40 \times 40 \mathrm{~mm}$ surfaces were covered with wax so carbonation would proceed across the long sides only. The samples were stored and their weights monitored under these conditions throughout. The analyses described below were performed after carbonation was essentially complete, defined to be when the weight remained constant, since the free portlandite is never entirely consumed (17). 
Se cortaron algunas probetas de $10 \times 10 \times 10 \mathrm{~mm}$ de las probetas prismáticas, con el fin de curarlas en una atmósfera de $\mathrm{CO}_{2}$, después de secarlas en una cámara con silicagel. Se aplicó vacío para eliminar el aire del sistema poroso de las probetas. Después, la cámara se llenó con $\mathrm{CO}_{2}$ comercial $\left(100 \% \mathrm{CO}_{2}\right.$ a presión atmosférica), hasta que las probetas quedaron totalmente carbonatadas (18) (el peso de las probetas permaneció constante en el tiempo).

\subsection{Metodología analítica}

\subsubsection{Estructura porosa}

La estructura porosa fue analizada de dos formas:

- Porosidad abierta: la porosidad total es expresada como $\mathrm{P}$, en porcentaje, y es determinada de acuerdo a la prueba de saturación en agua (19) con una balanza hidrostática.

- Distribución de tamaño de poro: calculada usando la porosimetría por intrusión de mercurio con un porosímetro de mercurio Micrometrics 9320 Poresizer, con registro automático de presión, de diámetro de poro, de volumen de intrusión y de área superficial de poro.

\subsubsection{Contenido en agua}

Para evaluar el contenido en agua se empleó una cámara climática (CCI FCH-Xenolab). Las muestras fueron pesadas después de ser calentadas a $105^{\circ} \mathrm{C}$ y almacenadas en la cámara climática a $20^{\circ} \mathrm{C}$ y a las diferentes humedades relativas $(0,20,30,40,50,60,70,80,90,95$ y 99\%).

\section{RESULTADOS Y DISCUSIÓN}

\subsection{Estructura porosa}

La distribución de tamaño de poro en las pastas mixtas de cal y cemento cambia gradualmente con el incremento del porcentaje de cemento. Esto se debe a la diferencia de morfología entre la cal y el cemento. La cal es un agregado de cristales, cuya distribución de tamaño de poro está en función del tamaño de partícula y de la relación A/C (agua/conglomerante) (13). En las pastas de cemento, después del proceso de hidratación, los silicatos cálcicos hidratados poseen estructura de gel (14), dando lugar a poros irregulares. En consecuencia, las pastas mixtas son una mezcla de sendas morfologías, siendo la resultante en función del porcentaje de ambos componentes. La Tabla 3 muestra cómo la porosidad decrece con el incremento del porcentaje de cemento debido a la menor cantidad de agua de amasado usada en las pastas con alto contenido en cemento para obtener la misma trabajabilidad (Tabla 2).
A number of specimens measuring $10 \times 10 \times 10 \mathrm{~mm}$ were cut out of the initial specimens and dried in a chamber with silica gel. A vacuum was applied to remove the air from the pores in these specimens. They were then cured in a chamber filled with commercial $\mathrm{CO}_{2}$ (100\% $\mathrm{CO}_{2}$ at atmospheric pressure) until the they were totally carbonated (18) (i.e., when they reached a constant weight).

\subsection{Analytical methodology}

\subsubsection{Pore structure}

The pore structure was analyzed in two ways:

- Open porosity: total porosity or $P$, expressed in percentage, was determined by the water saturation test (19) using a hydrostatic scales.

- Pore size distribution: calculated using a Micrometrics 9320 Poresizer mercury intrusion porosimeter that automatically records pressure, pore diameter, intrusion volume and pore surface area.

\subsubsection{Water content}

A (CCI FCH-Xenolab) climatic chamber was used to evaluate water content. The samples were weighed after heating to $105^{\circ} \mathrm{C}$ and stored in a climatic chamber at $20{ }^{\circ} \mathrm{C}$ and different relative humidities $(0,20,30,40$, 50, 60, 70, 80, 90, 95 and 99\%).

\section{RESULTS AND DISCUSSION}

\subsection{Pore structure}

The pore size distribution in blended lime and cement pastes changes gradually with the increase in the percentage of cement. This is due to differences in lime and cement morphology. Lime is a crystalline compound whose pore size distribution depends on particle size and the $W / B$ (water/binder) ratio (13). In cement pastes, the hydrated calcium silicates form a gel structure (14) with irregular pores. Consequently, the blended pastes are a mix of these two morphologies, with the end result depending on the percentage of the two components. Table 3 shows that porosity declined with increasing percentages of cement due to the lower amounts of water needed in high cement content pastes to obtain the same workability (Table 2). 
Las Figuras 1 y 2 muestran, como ejemplo, las distribuciones porosimétricas acumuladas de algunas de las muestras estudiadas y la derivada del volumen de intrusión respecto al diámetro, respectivamente. La distribución de tamaño de poro también cambia gradualmente con la composición. En pastas con alto porcentaje de cal, la gran mayoría de los poros están concentrados en un estrecho intervalo de diámetros $(0,3-0,8 \mu \mathrm{m})$, mientras que en las pastas con mayor cantidad de cemento, el intervalo de diámetros se incrementa dando lugar a distribuciones de poros más amplias $(0,003-0,6 \mu \mathrm{m})$.

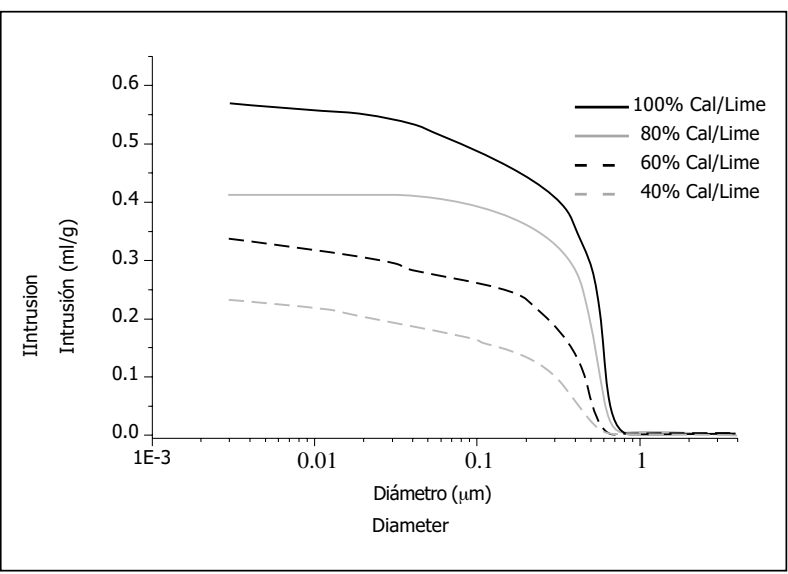

Figura 1. Distribución acumulada de tamaño de poro de cuatro de las pastas mixtas.

Figure 1. Cumulative pore size distribution of four of the blended pastes.

El volumen de intrusión decrece con el incremento de la cantidad de cemento, en concordancia con los datos de porosidad (Tabla 3). Como muestra la Figura 2, en pastas con un mayor porcentaje de cemento, el diámetro de poro principal se desplaza hacia diámetros de poro menores, con una intensa reducción que es traducida en un pico más ancho y achatado.

Sabiendo que el recorrido medio libre $(\lambda)$ para el aire es de $0,066 \mu \mathrm{m}$ (a $760 \mathrm{~mm} \mathrm{Hg}$ y $20^{\circ} \mathrm{C}$ ), y teniendo en cuenta los resultados de la distribución de tamaño de poro se pueden diferenciar tres partes en la estructura: i) una primera en la que tiene lugar la difusión de Fick (diámetro de poro $d \geq 10 \lambda$, es decir, $d \geq 0,66 \mu \mathrm{m}$ ); ii) una segunda en la que se dan una mezcla de la difusión de Fick y la de Knudsen $(\lambda \leq \mathrm{d}<10 \lambda$, es decir, 0,066 $\mu \mathrm{m} \leq \mathrm{d}<0,66 \mu \mathrm{m})$; iii) una tercera parte donde sólo tiene lugar la difusión de Knudsen $(\mathrm{d}<\lambda$, es decir, $\mathrm{d}<0,066 \mu \mathrm{m})$. Por tanto, cuando se incrementa el contenido en cemento de las pastas, también se incrementa el número de poros en los cuales se verifica la difusión de Knudsen en detrimento de aquellos en los que se produce la difusión de Fick.
By way of example, Figures 1 and 2 give the cumulative pore size distributions for some of the samples studied and the derivative of the intrusion volume plotted against the diameter, respectively. Pore size distribution was observed to change gradually with composition. In pastes with a high percentage of lime, the diameters of most of the pores fell within a narrow range (0.3-0.8 $\mu \mathrm{m})$, while in pastes with greater amounts of cement the range of diameters widened, giving rise to broader pore size distributions (0.003-0.6 $\mu \mathrm{m})$.

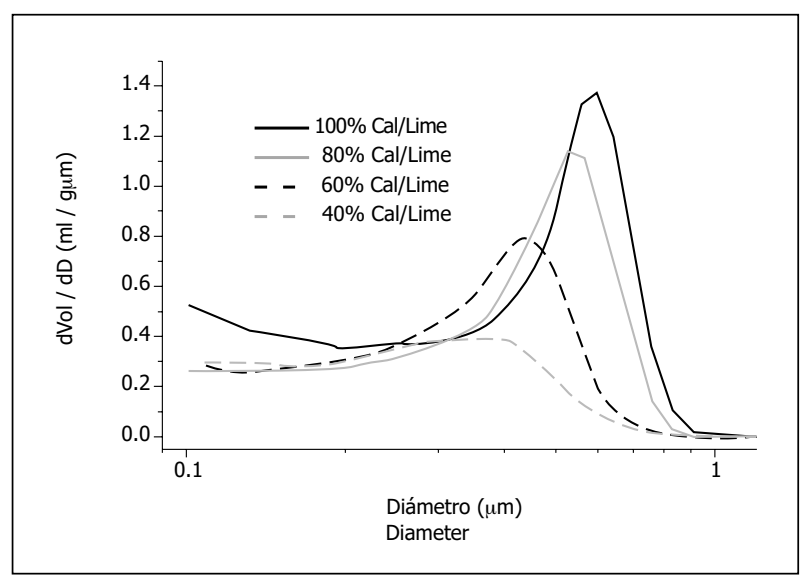

Figura 2. Derivada de la distribución de tamaño de poro de cuatro de las pastas mixtas.

Figure 2. Derivative pore size distribution of four of the blended pastes.

The intrusion volume dropped with increasing amounts of cement, a finding consistent with the porosity data (Table 3). As Figure 2 shows, in pastes with a higher percentage of cement, the median pore diameter shifted downward, while the sharp decline in the derivative of the distribution translated into a wider and flatter peak.

Knowing that the average free distance $(\lambda)$ that air can travel is $0.066 \mu \mathrm{m}$ (at $760 \mathrm{~mm}$ of $\mathrm{Hg}$ and $20^{\circ} \mathrm{C}$ ), and in light of the pore size distribution findings, the structure can be divided into three parts: i) a first in which diffusion follows Fick's law (pore diameter $d \geq 10 \lambda$, i.e., $d \geq$ $0.66 \mu \mathrm{m})$; ii) a second where both Fick and Knudsen diffusion are present ( $\lambda \leq d<10 \lambda$, i. e., $0.066 \mu \mathrm{m} \leq d<$ $0.66 \mu \mathrm{m})$; iii) and a third where only Knudsen diffusion is found $(d<\lambda$, i. e., $d<0.066 \mu \mathrm{m})$. Consequently, as the cement content in the pastes increases, the number of pores where Knudsen diffusion takes place rises at the expense of the pores where diffusion follows Fick's law. 
Tabla 3 / Table 3

Porosidad total de las diferentes pastas mixtas

Total porosity for the different blended pastes

\begin{tabular}{|lccccccc|}
\hline $\begin{array}{l}\text { Cal } \\
\text { Lime }\end{array}$ & $\mathbf{1 0 0 \%}$ & $\mathbf{9 0 \%}$ & $\mathbf{8 0 \%}$ & $\mathbf{7 0 \%}$ & $\mathbf{6 0 \%}$ & $\mathbf{5 0 \%}$ & $\mathbf{4 0 \%}$ \\
\hline Pa (\%) & 56.0 & 54.3 & 52.1 & 50.0 & 47.5 & 45.1 & 41.3 \\
\hline $\begin{array}{l}\text { D.E.* } \\
\text { S.D.* }\end{array}$ & 0.35 & 0.17 & 0.28 & 0.41 & 0.32 & 0.25 & 0.21 \\
\hline
\end{tabular}

* Desviación Estándar / Standard Deviation.

Si tiene lugar la difusión de Knudsen, el proceso de difusión será más complejo, y, por tanto, también lo serán los procesos de secado y carbonatación. Si la difusión de Knudsen adquiere mayor importancia, la microestructura también jugará un papel más importante como factor controlador en estos procesos, principalmente en lo referente a la tortuosidad del sistema (distancia que recorren las moléculas de gas entre el grosor del material). Se debe señalar que la difusión solamente se produce en los poros mayores que aquellos que son bloqueados por condensación capilar [Ecuación de Kelvin [2] (8)].
Knudsen diffusion, a more complex process, renders drying and carbonation more complex as well. Where Knudsen diffusion becomes more prevalent, blend microstructure also plays a more important role as a factor governing these processes, primarily in respect of system intricacy (the inward distance travelled by gas molecules in the material). Be it said that diffusion only takes place in pores large enough not to be obstructed by capillary condensation [Kelvin's Equation [2] (8)].

$$
-\operatorname{Ln}\left(p / p_{s}\right)=2 \cdot \gamma \cdot V / R \cdot T \cdot r
$$

donde $\mathrm{p}$ es la presión de vapor de agua, $\mathrm{p}_{\mathrm{s}}$ es la presión de vapor de agua en atmósfera saturada, $\gamma$ es la energía superficial específica del agua, $V$ es el volumen molar del agua, $\mathrm{R}$ es la constante de los gases, $\mathrm{T}$ es la temperatura y $r$ es el radio capilar.

\subsection{Contenido en agua higroscópica}

Las curvas higroscópicas obtenidas pueden ser explicadas fácilmente atendiendo a la microestructura de las pastas y a los cambios producidos como consecuencia de la variación de la composición. El comportamiento higroscópico mostrado en la Figura 3 puede ser dividido para su consideración en dos zonas diferentes: baja y alta humedad relativa. A baja humedad relativa $(\mathrm{HR}<50 \%)$, para las pastas ricas en cemento, el incremento en agua puede ser debido al aumento de la superficie específica, según muestran los valores de este parámetro recogidos en un trabajo previo (18), como consecuencia del tipo de morfología del gel, que ofrece mayor superficie específica que los cristales de la cal. A mayores humedades relativas ( $\mathrm{HR}>50 \%)$, el agua condensa en los poros más pequeños (que no están presentes en las pastas de cal). Es en estos poros en los que la Ecuación de Kelvin [2] puede verificarse. El contenido en agua de las pastas ricas en cemento se incrementa como consecuencia del incremento de la cantidad de poros gel. En las condiciones de trabajo where $p$ is water vapour pressure, $p_{s}$ water vapour pressure in a saturated atmosphere, $\gamma$ the specific surface energy for water, $V$ the molar volume of water, $R$ the universal gas constant, $T$ temperature and $r$ the capillary radius.

\subsection{Hygroscopic water content}

The hygroscopic curves obtained can be readily explained in terms of paste microstructure and the changes taking place as a result of varying composition. The hygroscopic curves in Figure 3 behave differently at low and high relative humidity. Where relative humidity is low $(\mathrm{RH}<50 \%)$, the increase in water in pastes with a high cement content may be due to the rise in specific surface, as shown by the values for this parameter reported in a previous paper (18), which is greater in their gel-type morphology than in lime crystals. At higher relative humidity values ( $\mathrm{RH}>50 \%)$, water condenses in the smaller pores (not present in the lime pastes). These are the pores where Kelvin's Equation [2] may hold. The water content in cement-rich pastes rises as a result of the increase in the number of gel-type pores. Under the conditions prevailing in the present survey (60\% RH and $\mathrm{T}=20^{\circ} \mathrm{C}$ ), pores smaller than $0.002 \mu \mathrm{m}$ (gel pores, deduced from [2] become water-saturated. Carbonation is slower in these pores because the $\mathrm{CO}_{2}$ 
$\left(60 \%\right.$ HR y $\left.20^{\circ} \mathrm{C}\right)$, los poros menores que $0,002 \mu \mathrm{m}$ (perteneciente a los poros gel y deducidos a partir de [2]) están saturados de agua. En estos poros la carbonatación es más lenta porque el $\mathrm{CO}_{2}$, tiene que alcanzar la pared del poro, pasando por difusión a través del agua condensada. has to diffuse through the condensed water to reach the pore wall.

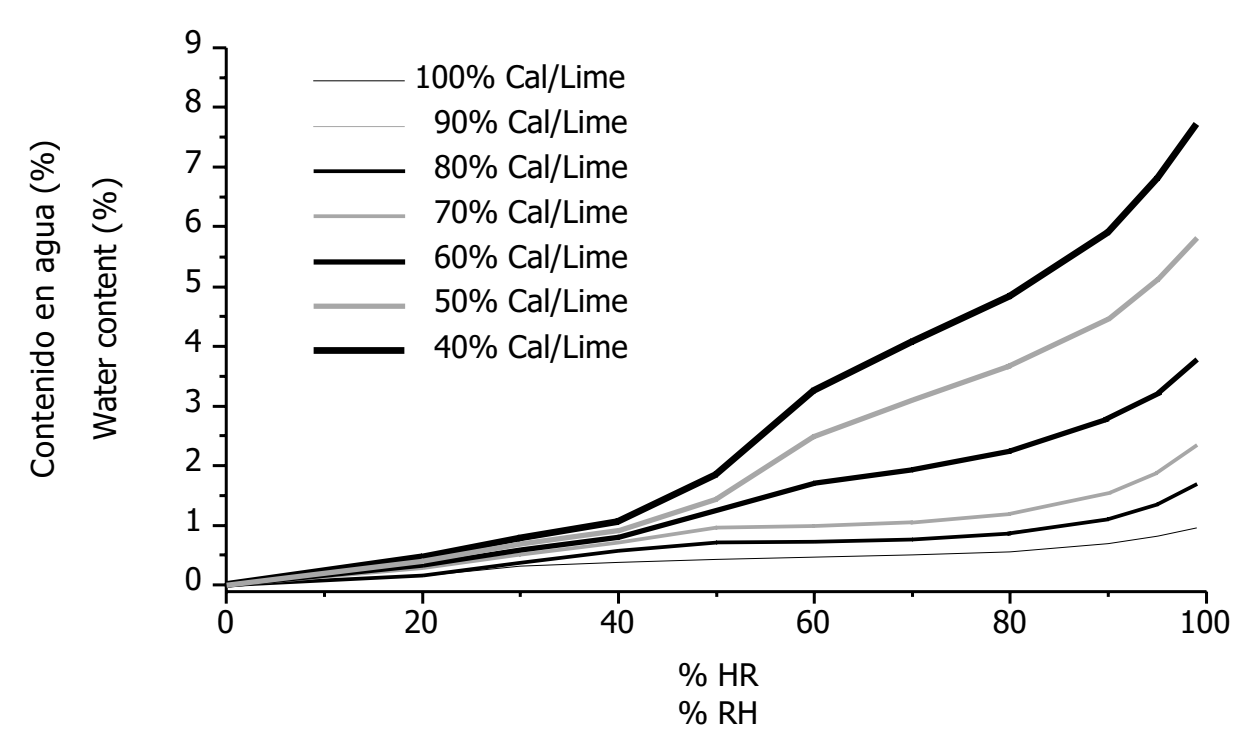

Figura 3. Curvas higroscópicas de las diferentes pastas mixtas.

Figure 3. Hygroscopic curves vs. \%RH for the blended pastes.

En definitiva, el contenido en agua higroscópica a una HR concreta (\% en peso) de las pastas mixtas está en función de la composición de la pasta, debido principalmente a la variación de la microestructura. El contenido en agua higroscópica se incrementa para las pastas ricas en cemento, aumentándose la diferencia debida a la composición para altas humedades relativas.

\subsection{Velocidad del proceso de carbonatación}

En la Tabla 4 se recogen para las diferentes pastas mixtas los tiempos de carbonatación total y las velocidades medias del proceso de carbonatación. La cantidad de $\mathrm{Ca}(\mathrm{OH})_{2}$ se calcula a partir de la cantidad de cal inicialmente incorporada a la mezcla, añadiendo un $5 \%$ sobre la masa inicial de cemento debido a la cantidad formada por la evolución del gel de CSH, que también producirá portlandita. A la vista de la bibliografía, se ha aceptado un error por defecto en esta cantidad, con idea de ponderar las posibles adiciones al cemento (calizas, fundamentalmente) que no generarán portlandita (20). No obstante, y dada la limitada cantidad de cemento en las mezclas, puede asumirse como preponderante la cal original, por lo que el error cometido no será excesivo.

Como muestran los resultados, el tiempo de carbonatación total se incrementa bruscamente al aumentar la
In short, the hygroscopic water content (\% by weight) in blended pastes at a given $\mathrm{RH}$ depends on paste composition, due primarily to microstructural variations. The hygroscopic water content climbs in cement-rich pastes, with the difference intensifying at high relative humidities due to the effect of composition.

\subsection{Carbonation rate}

Table 4 gives the total carbonation times and mean carbonation rates for the different blended pastes. The amount of $\mathrm{Ca}(\mathrm{OH})_{2}$ was computed from the amount of lime initially included in the mix, adding $5 \%$ by weight of the initial amount of cement to account for the calcium hydroxide appearing during $\mathrm{CSH}$ gel formation, a process in which portlandite is also produced. Based on the literature, this amount was acknowledged to fall short of the actual Figure, in light of the possible (essentially calcareous) cement additions that would not generate portlandite (20). Nonetheless, given the small amounts of cement in the blends, the original lime can be regarded to be predominant and any such error not overly large.

As the results show, the total carbonation time rose sharply when the amount of cement increased (particularly when 
Tabla 4 / Table 4

Tiempo de carbonatación total y velocidad de carbonatación media de las diferentes pastas mixtas Saturation time and average rate of carbonation for the different blended pastes

\begin{tabular}{|cccc|}
\hline $\begin{array}{c}\text { \% Cal } \\
\% \text { Lime }\end{array}$ & $\begin{array}{c}\text { Tiempo de carbonatación total }(\mathbf{h}) \\
\text { Total carbonation time }(\boldsymbol{h})\end{array}$ & $\mathbf{C a}(\mathbf{O H})_{\mathbf{2}} \mathbf{( g )}$ & $\begin{array}{c}\text { Velocidad media de carbonatación }(\mathbf{g} / \mathbf{h}) \\
\text { Average carbonation rate }(\mathbf{g} / \mathbf{h})\end{array}$ \\
\hline 100 & 4820 & 147 & 0.0305 \\
\hline 90 & 5500 & 137 & 0.0252 \\
\hline 80 & 6500 & 140 & 0.0220 \\
\hline 70 & 8000 & 133 & 0.0172 \\
\hline 60 & 10500 & 125 & 0.0125 \\
\hline 50 & 10000 & 112 & 0.0087 \\
\hline 40 & 17000 & 96 & 0.0063 \\
\hline
\end{tabular}

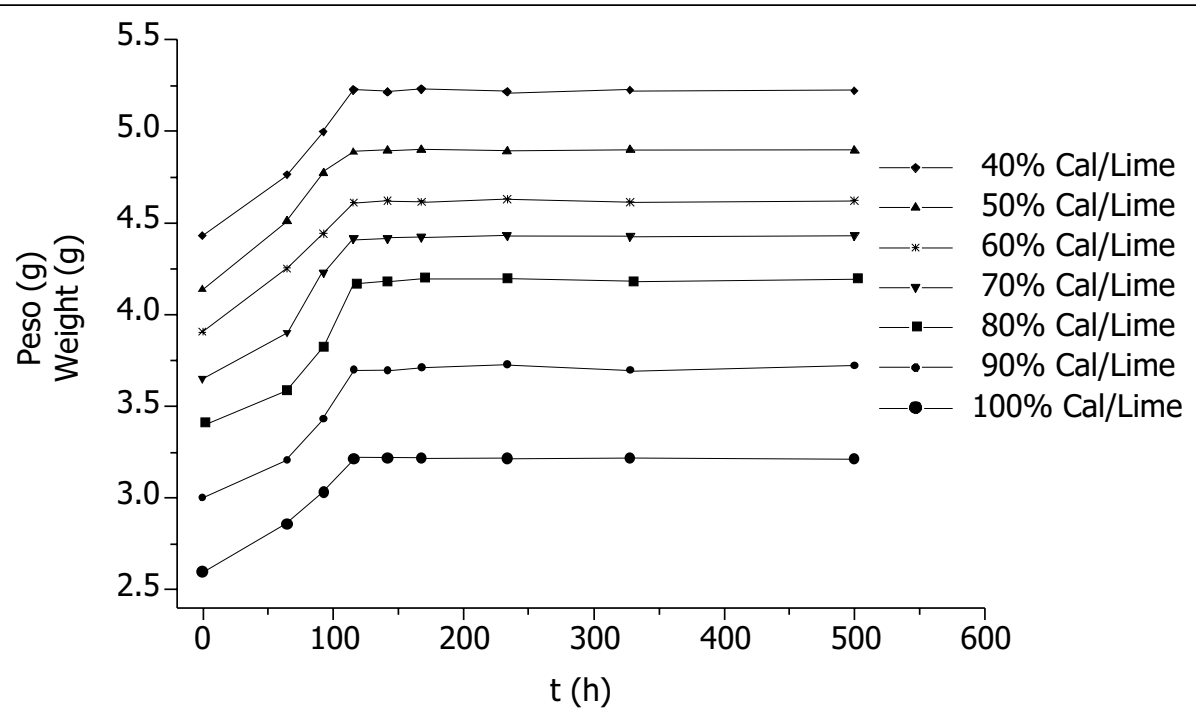

Figura 4. Carbonatación forzada: representación del peso de las probetas vs. tiempo, en una atmósfera $100 \% \mathrm{CO}_{2}$. Figure 4. Weight of the specimens vs. time, with forced carbonation in a $100 \% \mathrm{CO}_{2}$ atmosphere.

cantidad de cemento (en especial cuando se supera el $30 \%$ de cemento), disminuyendo la velocidad media del proceso. La disminución de la velocidad puede justificarse por la menor porosidad (Tabla 3) y por un desplazamiento de la distribución de tamaño de poros hacia poros de diámetro menor (Figuras 1 y 2), lo que produce una peor difusión que ocasiona un secado y una carbonatación más lentos.

La Figura 4 muestra la evolución del peso de algunas probetas durante una carbonatación forzada en atmósfera de $\mathrm{CO}_{2}$. Todas las pastas alcanzan pesos constantes al mismo tiempo independientemente de la composición del conglomerante, hecho opuesto a la carbonatación natural. Este fenómeno permite excluir a la difusión como factor limitante. En la carbonatación forzada, el proceso es controlado por la reacción, siendo la disolución del $\mathrm{Ca}(\mathrm{OH})_{2}$ la etapa más lenta. Por esta razón, el the cement content exceeded $30 \%$ ), reducing the mean carbonation rate. This decrease can be explained by declining porosity (Table 3) and the shift in pore size towards smaller diameter pores (Figures 1 and 2). The resulting less efficient diffusion occasioned slower drying and carbonation.

Figure 4 gives the weights of some of the specimens during forced carbonation in a $\mathrm{CO}_{2}$-rich atmosphere. Contrary to findings for natural carbonation, all the pastes reached constant weights within the same period of time, regardless of binder composition. This observation excludes diffusion as a limiting factor. In forced carbonation the process is controlled by the reaction, in which $\mathrm{Ca}(\mathrm{OH})_{2}$ dissolution is the slowest step. Hence, particle size and water content are the most important parameters 
tamaño de partícula y el contenido en agua son los parámetros más importantes, porque la disolución del $\mathrm{Ca}(\mathrm{OH})_{2}$ depende del área de contacto entre el $\mathrm{Ca}(\mathrm{OH})_{2}$ y el agua. Se puede establecer que el proceso de carbonatación en una atmósfera de $\mathrm{CO}_{2}$ no depende de la estructura porosa de la pasta, de forma opuesta a la carbonatación natural o carbonatación no forzada (controlada por difusión).

La variación de peso debido a la carbonatación del $\mathrm{Ca}(\mathrm{OH})_{2}$ puede ser descrita por medio de [3]: because $\mathrm{Ca}(\mathrm{OH})_{2}$ dissolution depends on the $\mathrm{Ca}(\mathrm{OH})_{2}-$ water contact area. Contrary to events in natural or nonforced (diffusion-controlled) carbonation, in a $\mathrm{CO}_{2}$-rich atmosphere carbonation can be shown to be independent from the pore structure of the paste.

The variation in weight owing to $\mathrm{Ca}(\mathrm{OH})_{2}$ carbonation can be described by Equation [3]:

$$
W=\mathrm{A} \sqrt{t}
$$

donde $W$ es el peso ganado por unidad de área $\left(\mathrm{g} / \mathrm{cm}^{2}\right)$, A es un nuevo parámetro $\left(\mathrm{g} / \mathrm{cm}^{2} \cdot \mathrm{s}^{1 / 2}\right)$ y $\mathrm{t}$ es el tiempo. Con el objeto de evitar interferencias con los procesos de secado e hidratación del $\mathrm{C}_{3} \mathrm{~S}$ (15), únicamente se ha considerado la carbonatación de la última mitad del $\mathrm{Ca}(\mathrm{OH})_{2}$ de las probetas. Aunque la hidratación del $\mathrm{C}_{2} \mathrm{~S}$ (que tiene lugar a plazo medio-largo) también pudiera tener su influencia, ésta se ha despreciado por varias razones: i) la menor cantidad de esta fase en el tipo de cemento utilizado (21-23); ii) la relativamente escasa proporción de cemento en las mezclas estudiadas; y iii) porque los datos registrados han sido recogidos durante largos plazos (superiores a 8 meses) en donde puede asumirse que la mayor parte de $\mathrm{C}_{2} \mathrm{~S}$ esté ya hidratada (15). Como muestra la Tabla 5, el parámetro A disminuye con el incremento de cemento en la pasta. Como se ha explicado anteriormente, la carbonatación se produce de una forma más lenta en las pastas ricas en cemento debido a una peor difusión del gas como consecuencia de su estructura porosa. Se ha visto, como muestra la Figura 5, que el parámetro $A$ es inversamente proporcional al porcentaje de cemento en la pasta $\left(R^{2}=0,9974, p<0,0001\right)$. where $W$ is the weight gain per unit of area $\left(\mathrm{g} / \mathrm{cm}^{2}\right), A$ is a new parameter $\left(\mathrm{g} / \mathrm{cm}^{2} \cdot \mathrm{s}^{1 / 2}\right)$ and $t$ is time. Only the carbonation of the last half of the $\mathrm{Ca}(\mathrm{OH})_{2}$ in the specimens was considered, to prevent interference with rying and $C_{3} S$ hydration (15). Although $C_{2} S$ hydration (which takes place in the medium-long term) may also have an impact on the results, it was neglected for a number of reasons: $i)$ the tiny amounts of this phase in the type of cement used (21-23); ii) the relatively scant proportion of cement in the blends studied; and iii) the fact that most of the $C_{2} S$ can be assumed to be hydrated because the data recorded were collected over long periods of time (more than 8 months) (15). Table 5 shows that parameter $A$ decreases with increased cement content in the paste. As explained above, carbonation takes place more slowly in cement-rich pastes due to less efficient gas diffusion as a result of the pore structure characteristics. Figure 5, in turn, confirms that parameter $A$ is inversely proportional to the percentage of cement in the paste $\left(R^{2}=0.9974, p<0.0001\right)$.

Tabla 5 / Table 5

Parámetros $A, B$ y $B_{A}$ para las diferentes pastas mixtas

$A, B$ and $B_{A}$ parameters for the blended pastes

\begin{tabular}{|c|c|c|c|c|c|c|c|}
\hline Cal/Lime & $100 \%$ & $90 \%$ & $80 \%$ & $70 \%$ & $60 \%$ & $50 \%$ & $40 \%$ \\
\hline$A\left(\mathrm{~g} / \mathrm{cm}^{2} \cdot \mathrm{h}^{1 / 2}\right)$ & 0.00346 & 0.00307 & 0.00282 & 0.00253 & 0.00206 & 0.00159 & 0.00131 \\
\hline $\mathrm{k}$ & 0.22 & 0.20 & 0.18 & 0.16 & 0.14 & 0.12 & 0.10 \\
\hline$p\left(\mathrm{~g} / \mathrm{cm}^{3}\right)$ & 1.04 & 1.08 & 1.19 & 1.27 & 1.37 & 1.46 & 1.54 \\
\hline $\begin{array}{l}\text { Área de la probeta } \\
\text { Specimen area } \\
\left(\mathrm{cm}^{2}\right)^{*}\end{array}$ & 14.44 & 14.63 & 15.01 & 15.21 & 15.37 & 15.45 & 15.6 \\
\hline $\begin{array}{l}\text { Perímetro de la probeta } \\
\text { Specimen perimeter } \\
(\mathrm{cm})^{*}\end{array}$ & 13.47 & 13.56 & 13.73 & 13.82 & 13.89 & 13.93 & 14.00 \\
\hline $\mathrm{BA}^{* *}\left(\mathrm{~cm} \cdot \mathrm{h}^{-1 / 2}\right)$ & 0.0150 & 0.0142 & 0.0131 & 0.0125 & 0.0107 & 0.0091 & 0.0086 \\
\hline $\mathrm{B}\left(\mathrm{cm} \cdot \mathrm{h}^{-1 / 2}\right)$ & 0.0150 & 0.0145 & 0.0136 & 0.0123 & 0.0108 & 0.0094 & 0.0085 \\
\hline
\end{tabular}

* Ambos valores se obtuvieron considerando la retracción de las probetas / Both values obtained making provision for specimen shrinkage.

** Calculados de los valores de A / Calculated fron the values of $A$. 
Se acepta que la Ecuación [4], derivada de la difusión de Fick, describe el movimiento del frente de carbonatación (8):
Equation [4], derived from Fick's law, is assumed to describe carbonation front movement (8):

$$
x=\mathrm{B} \sqrt{t}
$$

donde $x$ es la profundidad de carbonatación (cm), B es una constante $\left(\mathrm{cm} / \mathrm{s}^{1 / 2}\right)$ y t es el tiempo. El mismo estudio puede ser llevado a cabo entendiendo x como el área carbonatada $\left(\mathrm{cm}^{2}\right)$ por el perímetro a través del cual tiene lugar la carbonatación (cm). De esta forma, el estudio puede ser aplicado a probetas que carbonatan por varias caras, pero todas ellas paralelas a un eje perpendicular al plano de carbonatación de estudio. El estudio del frente de carbonatación a través de una cara es un caso particular de este estudio general, que presenta la ventaja de no estar influenciado por las discontinuidades del frente de carbonatación observadas con el método de la fenolftaleína (5). Dados el área carbonatada (teniendo en cuenta la retracción de la probeta) cuyos valores se presentan, y el perímetro a través del cual carbonata la probeta y el tiempo de carbonatación, puede calcularse el parámetro B (Tabla 5). Este parámetro se determina dividiendo el área carbonatada entre el perímetro de carbonatación (para conocer el frente de carbonatación), y, a su vez, a partir de la Ecuación [4], ese cociente se divide entre $t^{1 / 2}$ (tiempo de carbonatación de la probeta).

En algunos trabajos, se ha documentado el uso de otros exponentes diferentes a $t 0,5$, para obtener un mejor ajuste (24). La desviación de $t^{0,5}$ es debida a la complejidad de la microestructura y a que la difusión de Fick empieza a predominar en las pastas con un alto porcentaje en cemento. El parámetro $\mathrm{B}$ disminuye con el incremento del porcentaje de cemento en la pasta. También se ha establecido que el parámetro $B$ es inversamente proporcional al porcentaje de cemento en la pasta $\left(R^{2}=0,9981, p<0,0001\right.$ ) (Figura 6).

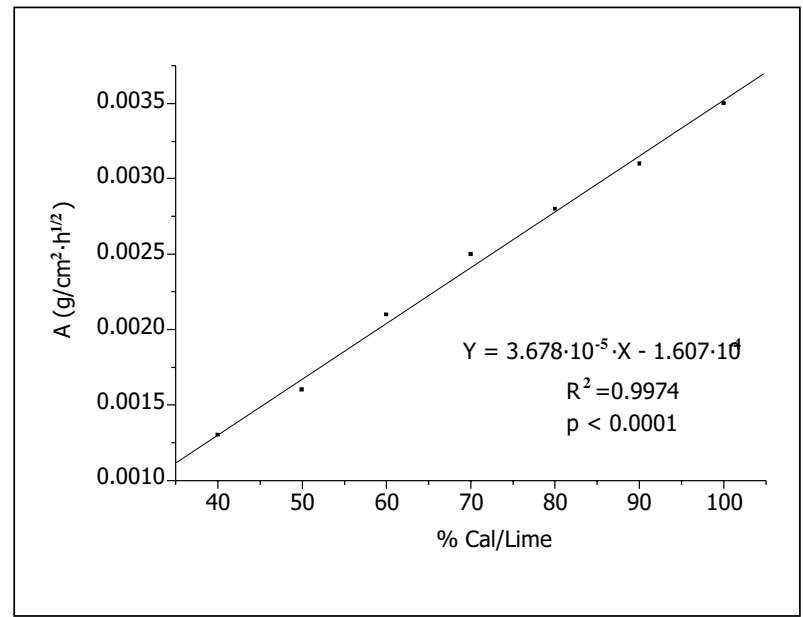

Figura 5. Parámetros A vs. porcentaje de cal en la pasta.

Figure 5. Parameter A vs. the percentage of lime in the paste. where $x$ is the carbonation depth (cm), B is a constant $\left(\mathrm{cm} / \mathrm{s}^{1 / 2}\right)$ and $t$ is time. The same analysis can be performed assuming $x$ to be the carbonated area $\left(\mathrm{cm}^{2}\right)$ times the carbonation perimeter $(\mathrm{cm})$. Consequently, the study can be applied to specimens carbonating on several surfaces, all parallel to a line perpendicular to the carbonation plane under study. In the study of the carbonation front along only one side, a specific case of this general approach, the advantage is that it is unaffected by the carbonation front discontinuities observed in the phenolphthalein method (5). Parameter B (Table 5) is found by dividing the carbonated area (making provision for specimen shrinkage) as shown by the carbonation perimeter (to determine the carbonation front) and, pursuant to Equation [4], that quotient is in turn divided by $t^{1 / 2}$ (specimen carbonation time).

Some authors have documented the use of exponents other than 0.5 for $t$, to achieve a better fit (24). The deviation in $t^{0.5}$ is due to microstructural complexities and to the fact that diffusion in the pastes with a high cement content tends to be governed by Fick's law. Parameter $B$ decreases with the increase in the percentage of cement in the paste. Parameter $B$ also proves to be inversely proportional to the percentage of cement in the paste $\left(R^{2}=0.9981, p<0.0001\right)$ (Figure 6).

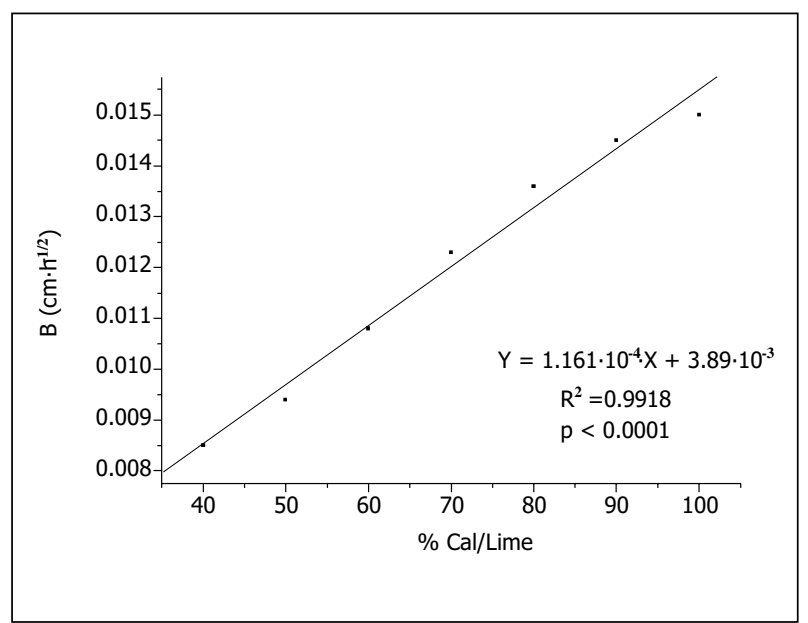

Figura 6. Parámetros B vs. porcentaje de cal en la pasta.

Figure 6. Parameter $B$ vs. the percentage of lime in the paste. 
Para pastas mixtas de cemento y cal ambos parámetros A y $B$ pueden relacionarse a través de la Ecuación [5]:
For blended cement and lime pastes, the two parameters, $A$ and $B$, can be related as in Equation [5]:

$$
B_{A}=\frac{A}{\kappa \cdot \rho}
$$

donde $\kappa$ [g (ganados debido a la carbonatación)/g (material)] y $\rho\left(\mathrm{g} / \mathrm{cm}^{3}\right)$ son las constantes del material, $\rho$ es definido como la compactación del material (o como la densidad). En el caso de las pastas mixtas, se debe tener en cuenta que la constante $\kappa$ cambia de unas pastas a otras debido al cambio en la composición del conglomerante. Por tanto, para cada pasta se puede definir una constante $\kappa$, que depende de su composición y una constante $\rho$, que está en función de la densidad ( $y$, por tanto, de su porosidad).

El parámetro $B_{A}$ se obtiene de la Ecuación [5], a partir de los valores de $A$. En la Tabla 5 , se puede ver que ambos parámetros $\mathrm{B}$ y $\mathrm{B}_{\mathrm{A}}$ obtenidos a partir de datos diferentes, tienen el mismo valor: B se ha calculado a partir de [4], incluyendo todos los procesos del curado (secado, carbonatación e hidratación del $\mathrm{C}_{3} \mathrm{~S}$ ), mientras que $\mathrm{B}_{\mathrm{A}}$ se ha calculado únicamente a partir de la carbonatación de la ultima mitad el $\mathrm{Ca}(\mathrm{OH})_{2}$. La similitud entre los valores de $\mathrm{B}$ y de $B_{A}$ permite establecer que en las pastas mixtas de cal y cemento con bajas cantidades de este último, el proceso de secado y el de hidratación del $\mathrm{C}_{3} \mathrm{~S}$ no retrasan el proceso de carbonatación de la cal de la mezcla. Este hecho puede ser explicado porque la carbonatación, al igual que el proceso de secado, tiene lugar desde la parte externa de la probeta hacia el interior. Pero, además, el proceso de secado es más rápido que la carbonatación, por lo que el área que se va a carbonatar ya ha perdido el exceso de agua en el momento de su carbonatación, por tanto, no hay interferencia entre ambos procesos. Con respecto a la hidratación del $\mathrm{C}_{3} \mathrm{~S}$, este proceso empieza en un corto período de tiempo, tratándose de un proceso rápido que, además, si la pasta está adecuadamente mezclada con agua tiene lugar de forma simultánea en toda la pasta al mismo tiempo, por lo que tampoco debería interferir con la carbonatación de la cal de la mezcla.

\section{CONCLUSIONES}

1. En las pastas mixtas con bajas cantidades de cemento, la condensación capilar se incrementa con el porcentaje de cemento en la pasta, debido al incremento del número de poros que cumplen la Ecuación de Kelvin a las distintas humedades relativas, por lo que el contenido en agua se incrementa al aumentar el contenido de cemento en las pastas.

2. Para cada pasta mixta, se ha establecido que el valor del parámetro A varía de forma inversamente proporcional where $\kappa[g$ (gained due to carbonation)/g (material)] and $\rho\left(\mathrm{g} / \mathrm{cm}^{3}\right)$ are material constants, $\rho$ being defined to be material consolidation (or density). In blended pastes, constant $\kappa$ changes from one paste to another due to changes in binder composition. Therefore, a different value of $\kappa$ may be defined for each paste, depending on its composition and a second constant, $\rho$, which depends on density (and therefore porosity).

Equation [5] is used to find parameter $B_{A}$ from the value of $A$. Table 5 shows that the values of the two parameters, $B$ and $B_{A}$ are virtually identical, despite being obtained from different data: B was calculated from [4], including all the curing processes (drying, carbonation and $C_{3} S$ hydration), whilst $B_{A}$ was computed simply from the carbonation of the final half of the $\mathrm{Ca}(\mathrm{OH})_{2}$. It may be deduced from the similarity in the values for $B$ and $B A$ that in lime and cement blends with low cement contents, drying and $C_{3} S$ hydration do not retard the carbonation of the lime in the mix. This may be explained by the fact that carbonation, like drying, takes place from outside in on the specimen. Moreover, since drying is a speedier process than carbonation, by the time an area is to be carbonated it has already lost any excess water; hence there is no interference between the two processes. $C_{3} S$ hydration, in turn, is also a rapid process that begins early on and, if the binder is suitably mixed with water, proceeds simultaneously throughout the entire specimen. Consequently, it should not interfere with the carbonation of the lime in the mix, either.

\section{CONCLUSIONS}

1. In blended pastes with small amounts of cement, capillary condensation increases with the percentage of cement in the paste due to the increase in the number of Kelvin Equation-compliant pores at all values of relative humidity. Therefore, the water content grows with the cement content in the pastes.

2. The value of parameter $A$ is inversely proportional to the percentage of paste in each blend, due to less 
con el porcentaje de cemento en la pasta, debido a una peor difusión (la difusión de Knudsen toma mayor protagonismo) como consecuencia de la estructura porosa: pastas menos porosas y poros más pequeños. El parámetro B también varía de forma inversamente proporcional con el porcentaje de cemento en la pasta.

3. Cuando el porcentaje de cemento se incrementa dando lugar a una microestructura más compleja, a pesar de la lenta velocidad del proceso de secado, este proceso no retrasa el proceso de carbonatación, obteniéndose los mismos valores para $\mathrm{B}$ y $\mathrm{B}_{\mathrm{A}}$. La hidratación del $\mathrm{C}_{3} \mathrm{~S}$ que tiene lugar durante los primero días del proceso de curado tampoco retrasa el proceso de carbonatación.

\section{AGRADECIMIENTOS}

El presente estudio ha sido financiado por el Ministerio de Ciencia y Tecnología, Plan Nacional de Investigación, programa de Desarrollo e Innovación Tecnológica (I+D+I), Project MAT 2000-1347. efficient diffusion (Knudsen diffusion becomes more prevalent) as a result of the pore structure of pastes with fewer and smaller pores. Parameter $B$ is also inversely proportional to paste cement content.

3. The similarity between the values obtained for $B$ and $B_{A}$ indicates that despite the low drying rate when the cement percentage grows, giving rise to a more complex microstructure, this process does not retard carbonation. Nor is carbonation retarded by the $C_{3} S$ hydration taking place early on in the curing process.

\section{ACKNOWLEDGEMENTS}

This study was funded by the Ministry of Science and Technology, National Research Plan, Development and Technological Innovation (R\&D+i) programme, Project MAT 2000-1247.

\section{BIBLIOGRAFÍA/BIBLIOGRAPHY}

(1) Lanas, J., Pérez Bernal, J. L., Bello, M. A., Álvarez, J. I.: "Mechanical properties of natural hydraulic lime-based mortars", Cem. Concr. Res., 34 (2004), pp. 2191-2201.

(2) Lanas, J., Álvarez, J. I.: "Masonry repair lime-based mortars: Factors affecting the mechanical behaviour", Cem. Concr. Res., 33 (2003), pp. 1867-1876.

(3) Degryse, P., Elsen, J., Waelkens, M.: "Study of ancient mortars from Salassos (Turkey) in view of their conservation", Cem. Concr. Res., 32 (2002), pp. 1457-1563.

(4) Houst, Y. F.; Wittmann, F. H.: "Influence of porosity and water content on the diffusivity of $\mathrm{CO}_{2}$ through hydrated cement paste", Cem. Concr. Res., 24 (1994), pp. 1165-1176.

(5) Rodríguez-Navarro, C., Cazalla, O.: "Liesegang pattern development in carbonation traditional lime mortars", Proc. R. Soc. Lond., 458 (2002), pp. 2261-2273.

(6) Steffens, A., Dinkler, D., Ahrens, H.: "Modelling carbonation for corrosion rick prediction of concrete structures", Cem. Concr. Res., 32 (2002), pp. 935-941.

(7) Lo, Y., Lee, H. M.: "Curing effects on carbonation of concrete using a phenolphthalein indicator and Fourier-transform infrared spectroscopy", Build. Environ., 37 (2002), pp. 507-514.

(8) Van Balen, K.; Van Gemert, D.: "Modelling lime mortar carbonation", Mater. Struct., 27 (1994), pp. 393-398.

(9) Cultrone, G., Sebastián, E., Ortega, M.: "Forced and natural carbonation of lime-based mortars with and without additives: Mineralogical and textural changes", Cem. Concr. Res. (2005). (Disponible on line, sciencedirect.com.)

(10) Stazi, A., D'Orazio, M., Quagliarini, E.: "In-life prediction of hydrometric behaviour of building materials: an application of fractal geometry to the determination of adsorption and suction properties", Build. Environ., 37 (2002), pp. 733-739.

(11) Weimann, M. B., Li, V. C.: "Hydral behaviour of engineered cementitious composites (ECC)", Restoration of Building and Monuments., 9 (5) (2003), pp. 513-534.

(12) Arandigoyen, M., Álvarez, J. I.: "Proceso de Carbonatación en pastas de cal con distinta relación Agua/Conglomerante", Mater. Construcc. n. 281 (2005), pp 5-18.

(13) Arandigoyen, M., Pérez Bernal, J. L., Bello López, M. A., Álvarez, J. I.: "Lime pastes with different kneading water: pore structure and capillary porosity", Appl. Surf. Sci., 252 (5) (2005), pp. 1449-1459.

(14) Scherer, G. W.: "Structure and properties of gels", Cem. Concr. Res., 29 (1999), pp. 1149-1157.

(15) Lea, F. M.: The chemistry of cement and concrete, Glasgow, Edward Arnold (1970).

(16) Martín, A.: Ensayos y experiencias de alteración en la conservación de obras de piedra de interés histórico artístico, Madrid, Ed. Fundación Ramón Areces (1990).

(17) Arandigoyen, M., Álvarez, J. I.: "Blended pastes of cement and lime: Pore structure and capillary porosity", Appl. Surf. Sci., In Press, Corrected Proof, disponible on line, 11 november 2005.

(18) Arandigoyen, M., Bicer-Simsir, B., Álvarez, J. I., Lange, D. A.: "Variation of microstructure with carbonation in lime and blended pastes", Appl. Surf. Sci. (2005) (disponible en la web, Sciencedirect.com) 
(19) Rilem, Mater. Struct., 13 (1980), pp. 175-253.

(20) Zelic, J., Rusic, D., Veza, D., Krstulovic, R.: "The role of silica fume in the kinetics and mechanisms during the early stage of cement hydration", Cem. Concr. Res., 30 (2000), pp. 1655-1622.

(21) Emanuelson, A., Hansen, S., Viggh, E.: "A comparative study of ordinary and mineralised Portland cement clinker from two different production units Part I: Composition and hydration of the clinkers", Cem. Concr. Res., 33 (2003), pp. 1613-1621.

(22) Torre, A. G. de la, Losilla, E. R., Cabeza, A., Aranda, M. A. G.: "High-resolution synchrotron powder diffraction analysis of ordinary Portland cements: Phase coexistence of alite", Nucl. Instr. and Meth. in Phys. Res. B, 238 (2005), pp. 87-91.

(23) Stutzman, P.: "Scanning electron microscopy imaging of hydraulic cement microstructure", Cem. Concr. Res., 26 (2004), pp. $957-966$.

(24) Basheer, L., Kropp, J., Cleland, D. J.: "Assessment of the durability of concrete from its permeation properties: a review", Const. Build. Mat., 15 (2001), pp. 93-103. 